\title{
Looking through the curtain of history
}

\author{
Ramon Mihai Balogh, Ioana Ionel*, Dan Stepan \\ *Politehnica University of Timișoara, Faculty of Mechanical Engineering, Bv. M. \\ Viteazu, 1, 300222, Timisoara, Romania, \\ *ioana.ionel@upt.ro,
}

\begin{abstract}
The Banat region, situated at the geographic crossroads between Eastern and Western Europe, with a special history and a destiny often broken by the vicissitudes of time, is known for many primordialities, all certified without denial. One of them is the first railway track on the present territory of Romania. The present paper, without pretending to be very documented, is an attempt to call to mind certain achievements of the Banat inhabitants related to their creativity, wish of development and entrepreneurial spirit. It briefly presents the railway Oraviţa-Baziaş, inaugurated by 1854 (to carry cargo) and, later, used also to carry passengers, celebrates its $160^{\text {th }}$ anniversary this year. The paper also points out the sad fate of other initial routes of Romanian railways, in retrospect and prospect.
\end{abstract}

Key words: Baziaş, Oraviţa, railroad, primordialities, Banat

\section{Introduction}

Most Romanians have heard of the town from the Banat, the place called Baziaș, where the Danube enters the country. Moreover, at least the Banat inhabitants know that this is from where the first railway on the present territory of Romania departed, connecting Baziaș to Oravița.

The locality is important also for Serbians, because it houses an old convent, founded following the tradition by St. Sava himself. Many elements, thus, gather in order to give great importance to that place. Considering this, it seems hard to believe that Baziass is about to disappear, maintaining only the memories of its former glory [1].

\section{The sad story of the first railways crossing the Romanian territory}

In the mid-nineteenth century, the Banat entered into the European rail routes network, which expanded eastward until reaching also our region. According to a very well documented work, written by Şerban Lacriţeanu and Ilie Popescu, Istoricul tracţiunii feroviare din România [6] [The history of railway traction in Romania - own translation], vol. I (which deals with the period from 1854 to 1918), Bucharest, 2003, the Banat holds the priority among the Romanian regions having a railway (1854), followed by Transylvania (1858), Dobrogea (1860), Bucovina (1866), the Old Kingdom (1869-1875) and Bessarabia (1871).
The Hungarian State Railways (M.Á.V. Magyar Államvasutak) were founded only in 1868. Until then, since 1846, a number of private railways had operated on itsterritory. The same happened also in Austria, where St.E.G. (Österreichisch-Ungarische Staatseisenbahngesellschaft) owned the railways until June 1, 1891.

\subsection{Railway Oravita - Anina}

The most interesting railway track in Romania and in South-East Europe is thus in the Banat region. Built in a mountain region and surrounded by landscapes of rare beauty, the track is entirely an architectural monument, standing as a testimony for the human creativity and technical potential of the time.

The first railway line in Banat was opened at 20.08.1854 between the Danubian port Baziaş and the mountain location Oraviţa. The line length of $62.5 \mathrm{~km}$ served to transport coal from the coal region Steierdorf - Anina to the Danube and from there to Austria. The line route was Oraviţa Răcăjdia - Iam - Iassenova - Biserica Albă Bazias. This line was named the "line coal" (Kohlenbahn).

For transportation of coal between Oraviţa (Figure 1) and Anina (Figure 2), different technical solutions were adopted that ultimately were not effective technically and economically. Such, at the very beginning, animals were used for the transport 
in the galleries, after that horse transportation of coal through galleries or on slopes was used.

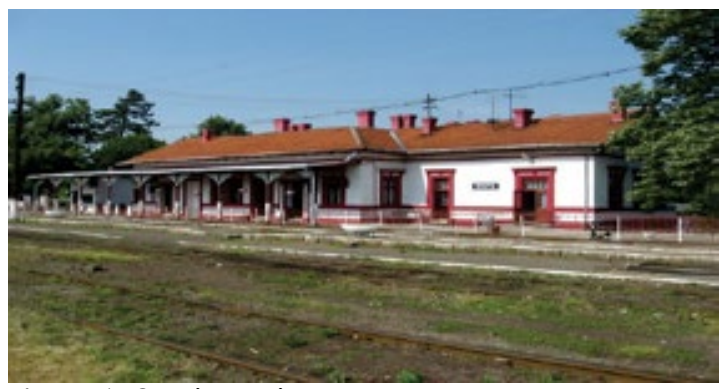

Figure 1. Oravita station

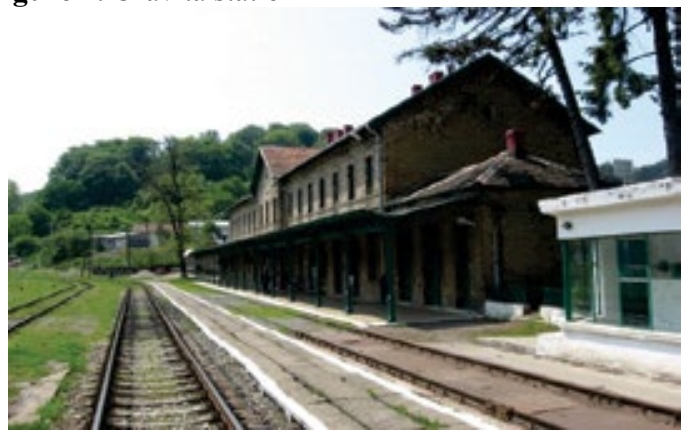

Figure 2. Anina station

Due to increasing quantities of coal to be transported on the Danube, one imposed the construction of a railway line linking Anina directly to the Danube harbor Baziaş.

Track construction began in the spring of 1861 and the opening for freight and passenger traffic was opened on December 15, 1863 (fig 3).

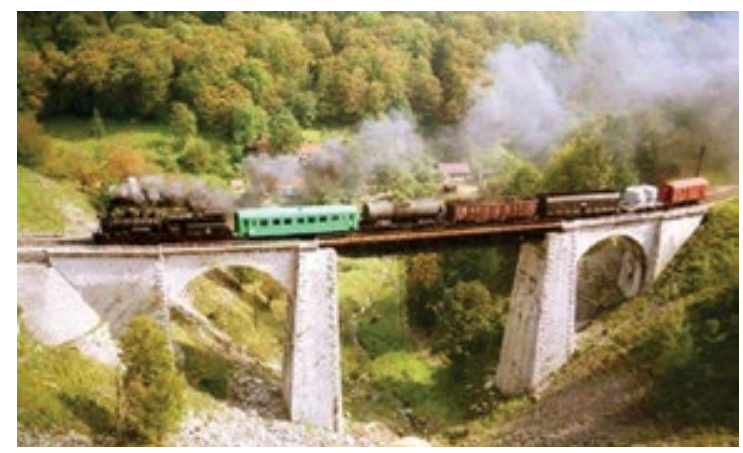

Figure 3. Mixed transport on Oravita-Anina [2]

Presently the line Oraviţa - Anina represents a special and unique engineering achievement. Called also the coal track, the railway Oraviţa-
Anina was made by St.E.G. having as model another European monument, the Semmering track in Austria. That had been built only a few years earlier, between 1845-1854 (compared to 18561863), between the mountain towns Gloggnitz and Mürzzuschlag in Styria, passing through the Semmering pass. It had $40 \mathrm{~km}$ (compared to 33.4) and a level difference of $388 \mathrm{~m}$ (compared to our $339 \mathrm{~m}$ ). The number of tunnels and viaducts of the two tracks is almost identical, fact which made the railway Oraviţa-Anina to be often referred to as the Banat Semmering. Locals and stone specialists brought from the Friuli region of northern Italy participated to its construction. The works were led by engineers Anton Rappos and Karl Dülnig and architects Karl Maniel and Johann Ludwig Dollhoff-Dier. The construction, which according to Georg Hromadka, cost a total of 5 million guilders, was put into operation on December 15, 1863 for freight and on April 4, 1869, for passengers $[3,11,12]$.

The line has 33,45 km (Figure 4) with 160 curves within 129 with radius les then $200 \mathrm{~m}, 14$ tunnels from which the greatest is Garliste with total length of $660 \mathrm{~m}, 10$ viaducts the highest has $35 \mathrm{~m}$, Jitin viaduc (Figure 5).

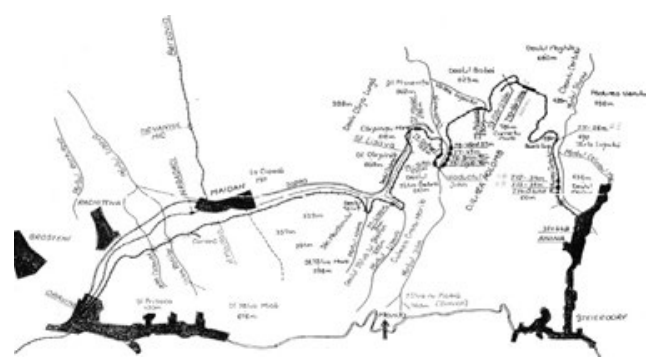

Figure 4. Oravita-Anina 33,45 km railway

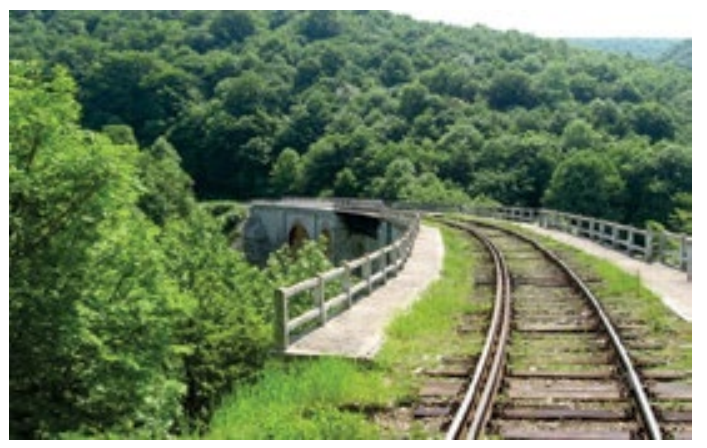

Figure 5. Jitin viaduct 
Built under the leadership of engineer Bach and using, from 1851, rail laminated at Reşiţa plants, the track Oraviţa-Baziaş was completed in 1854 , with a length of $62.5 \mathrm{~km}$. On August 20, 1854, the circulation of freight trains began and on November 1, 1856, that of passenger trains. The coal coming from the surroundings of Anina were loaded in the Baziass port on board of the ships belonging to the large Danube companies navigation, the most famous being D.D.S.G., founded in 1829 .

In parallel with the construction of the OraviţaBaziaş track, in 1847, a project belonging to engineer Anton Rappos was launched, providing for its extension by a normal steam traction track till Lişava. In this case, the coal would have been brought from Anina through a very long underground gallery, called King Ştefan, by horse driven wagons. But after 1852, with the increasing performances of steam traction, the Rappos project was radically altered, permanently abandoning the idea of underground galleries. By 1854, several funiculars were completed for the steeper section between Lişava and Anina. Then, the works to the track itself began. The track covers a distance of $33.4 \mathrm{~km}$, with a level difference of $339 \mathrm{~m}$. It has a total of 143 curves, of a length of $22.027 \mathrm{~m}$, representing $65.9 \%$ of the entire route. It must be mentioned that at that time dynamite had not yet been discovered, this being invented only in 1866 , three years after the works completion $[9,10]$.

After the closure of the mining operations on the route, the track was abandoned, as a strategy of C.F.R. (Romanian Railways) on November 1, 2010, being despoiled by scrape iron thieves. This is how another episode from the Banat railway history ended!

Considering its antiquity, the railway OravițaAnina is the fourth track on the present territory of Romania, but, considering its technical and architectural achievements, it is still unrivalled. Due to the track difficulty, the big level difference and the numerous curves crossed, it had always required special locomotives and wagons (Figure 6).

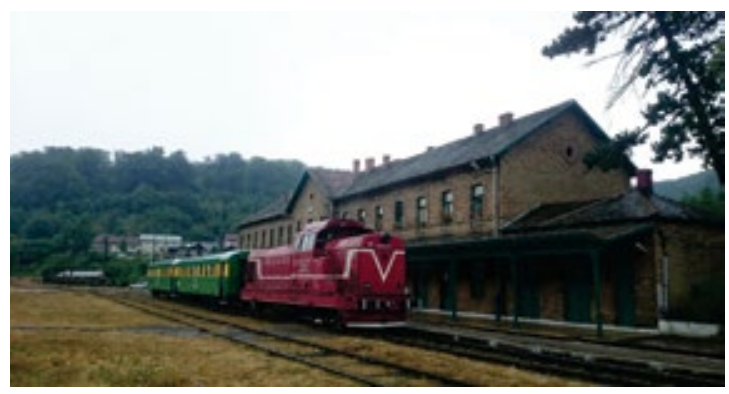

Figure 6. Anina-Oravita train [4]

Even fromits foundation, it had used a locomotive designed for it at St.E.G.'s factory in Vienna by engineer Pius Fink. Called Steyerdorf, it was made in 1861, followed by three others in 1867, namely Karaszova, Gerliste and Lisava. Used until 1891, these first locomotives between Oraviţa and Anina reached a maximum speed of 30 $\mathrm{km} / \mathrm{h}$. Their names are worth noting as they belong to the localities situated nearby the route travelled. Finally, the railway ended up having a total of seven halts and stations.

\subsection{Railway Oravita-Bazias}

In the early years, only one pair of mixed trains circulated per day between Oraviţa and Baziaş, as pointed out in The Mixed Railway Timetable on Oraviţa-Baziaş route, valid since November 15, 1857, published on April 18, 1858, in the newspaper Temesvarer Zeitung. The train used to leave Oraviţa at 7:00 a.m. and arrive in Baziaş at 10:02 a.m. From Baziaş, it used to leave back at 1:30 p.m., arriving in Oraviţa at 4:38 p.m. Its average speed was of $20.6 \mathrm{~km} / \mathrm{h}$. The traction was carried out from the beginning by locomotives built in 1852 by the company Günther from Wiener Neustadt, followed in 1855 by locomotive produced at St.E.G. Factory from Vienna, operating since 1840. The first locomotive distributed to the Oraviţa depot was no. 125 RESICZA and no. 126 ORAVICZA, taken over by St.E.G. in 1858 [15].

Over time, this railway was deeply marked by the political events happening in this side of Europe. After World War I, when the Banat was divided between Romania and Serbia, a $28 \mathrm{~km}$ segment of the total of 62.5 remained on Serbian territory. The train circulation was resumed on July 15,1922 , but only on the Romanian sector Oraviţa- 
Iam $(26.9 \mathrm{~km})$. Baziaş could be reached, until 1950, only on the track Timişoara-Jebel-VoitegStamora Moraviţa-Vârşeţ-Iasenova-Biserica AlbăVračev Gaj. In 1950, due to the conflict between Stalin and Tito, the train circulation on the territory of Yugoslavia was suspended, the section BaziaşSocol-(Vračev Gaj) and the Bridge Nera(Iasenova)-Iam being closed.

The first train coming from Oraviţa arrived, thus, in the Baziaş station in 1854. After two years, the new rail connection to Vienna by Timisoara turned this place into the terminus of European railways. Travelers arriving from Vienna or Paris embarked in Baziass on the vessels of the Danube companies, on which they continued to travel eastward, having as final destinations Constanța, Odessa, Istanbul and Alexandria. Baziaş had this important role only until 1879 , when the newly built track Timişoara-Caransebeş-Orşova made the connection with the Old Kingdom railways at Vârciorova, the rail route being thus much extended. However, until 1919, Baziaş continued to remain connected to Timişoara, facilitating the access of the Banat's capital to the trade on the Danube.

Due to the establishment of the border in its close proximity, Baziaş could no longer use neither the rail connection (completely closed in 1950), nor the port, dating from 1795 (Figure 7).

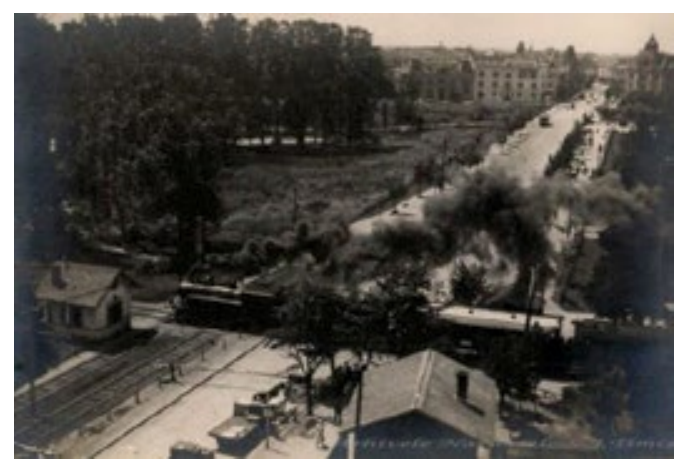

Figure 7: Timişoara-Baziaş track [5]

\subsection{Railway Seghedin-Timisoara-Bazias}

The first railway in present Romania, the one between Oraviţa and Baziaş, was followed shortly by another railway, much more important for the economic development of the Banat, the railwaySeghedin-Timişoara-Baziaş, opened in the years 1857-1858. Its builder, as for the majority of the railways in the Banat was St.E.G.

On November 15, 1857, $113.9 \mathrm{~km}$ belonging to the section of Seghedin - Jimbolia - Timişoara were inaugurated, out of which only $39 \mathrm{~km}$ were in the Romania of today. The first locomotives used on this railway were brought to Timişoara by boats on the Bega channel. They were called KOMÁROM, AUSTRIA, HONT and PESTH, being constructed in the years 1845-1846 at the Belgian factory John Cockerill in Seraing after the American model [6]. In July 1858, the Timişoara depot received the locomotives WARTBERG and LUGOS for passenger trains. It is interesting to highlight the way in which the newspaper Temesvarer Zeitung described the arrival of the first train to Timişoara: "When we hear the distant noise of the steam carriage, when we see the high train's chimney full of black smoke, it is as if we were charmed. And when it passes before us, we are almost astonished that we ourselves stand still in one place". This is how the history of the railway in the capital of the Banat began [13].

The historical data were excellently presented by Şerban Lacriţeanu and Ilie Popescu in their work, Istoricul tracţiunii feroviare din România [The history of railway traction in Romania - own translation], vol. I, published in Bucharest, in 2003, and will be presented in the following section.

The works started also for the other section, of $94 \mathrm{~km}$, between Timişoara-Jebel-Voiteg-Stamora Moraviţa-Vârşeţ-Iasenova, where it connected to the track Oraviţa-Baziaş. They were led by engineer Ludwig Meyer and began on December 10, 1856, in Vârşeţ and on December 27, 1856, in Iasenova and Şag. In order to build the numerous bridges on the route, cement produced from the burning of the limestone extracted from Oraviţa was used, as well as 7.5 million bricks produced in the seven brickyards placed along the route [13].

The first passenger train on the TimişoaraIasenova-Baziaş route (Figure 8) circulated on July 20, 1858, driven by the locomotive no. 111 WARTBERG, being composed by 11 passenger wagons and 1 luggage wagon.

The railway Seghedin-Timişoara-Baziaş connected the Banat region to major European rail routes, as it is here where, for a period of time, the connection between them and the river transport on the Danube was made. The terminus point of the 
railway, Baziaş represented also the beginning of a fluvial journey and then, a maritime journey of great interest to the people of the $19^{\text {th }}$ century, especially those thirsty for new. According to the Train timetable of May 6, 1861, of the St.E.G's southeast network between Vienna and Baziaş, a pair of high-speed trains circulated twice a week, which rode the entire distance of 86 Austrian miles in 28 hours and 18 minutes.

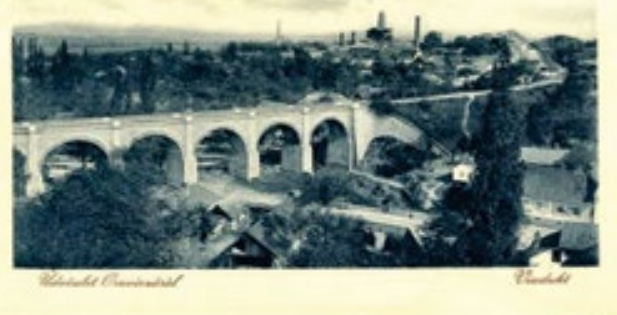

Figure 8: Viaduct, Bazias area [6]

The distance Pesta-Baziaş was covered in 11 hours and 18 minutes, and Timişoara-Baziaş in 3 hours and 6 minutes. The trains from Vienna used to arrive to Baziaş on Tuesdays and Fridays, the journey being continued from there using the boats of the D.D.S.G. [7] Company towards Orşova, Giurgiu, Cernavoda, Odessa and Constantinople. The timetable of these boats was connected to that of the trains belonging to the St.E.G. Company. The fast boats used to leave Baziaş on Tuesdays and Fridays at 8:30 a.m., while those for passengers on Thursdays at 11.30 a.m. The importance of the Timişoara-Iasenova-Baziaş track within the circuit of major international transport relations was maintained for two decades, until the inauguration on June 10, 1879, of the railway Timişoara-Caransebeş-Orşova-Vârciorova. This new railway, linked to those in the Romania of that time, offered the possibility to continue arailway journey to the Orient $[8,15]$.

During its peak, Baziaş was connected through Vienna, even with Paris and other major European centres. It was situated on the major route ParisConstantinople, the journey between these cities lasting six days (via Strasbourg, Karlsruhe, Stuttgart, Munich, with the variants Cologne, Hanover, Leipzig, Dresden, Prague, then Vienna, Baziaş, Cernavoda, Constanţa). The boats travelled the distance Baziaş-Cernavoda in 36 hours and 30 minutes, and back in 54 hours. The route ViennaBaziaş was justly called, for these reasons, the way to Orient. The years 1858-1879 represented Baziaş most flourishing period, when it was one of the most important points of connection between Eastern and Western Europe [9].

Not used since 1950, the monumental building of the Baziaş station was demolished after 1960, when it was thought that the place would be flooded by the raise of the Danube level once the Iron Gates dam was built. But, the place of the old station is now right on the shore, being occupied by the cottage Apus de soare (Sunrise, own translation). Nevertheless, most of the embankment of the former track between Baziaş and the border with Serbia was flooded by the river. This is how an episode from the Banat history on railway transport ended [15].

\section{Conclusions}

The sad story of the first railway that crossed also the present Romanian territory ends, although it has existed for almost a century (1854-1950). At present, the circulation is done only on certain sections. Nonetheless, its appearance and existence in this space of the Banat region are milestones in the history of railways and the human potential of the area. No annals on Romanian railways can omit this.

Other lines also had followed the same fate. Now, the only thing we can do is to write about and remember them! The viaducts and tunnels of these historic railways must become models, tailored to modern technology, models of power and perseverance. The constructions that have conquered so many hearts should not be forgotten and the railway Oravița-Anina must be kept and introduced in the tourist routes of the Banat region, with care and good local management.

We have no right to forget nor neglect what history has left us, all the more to show indifference towards the current situation, characterized by the lack of maintenance, publicity and visibility or by destruction (moral and material). 


\section{References}

[1] M. Rusnac - La kilometrul zero al Dunării bănățene, http://www.timisoaraonline.ro/timisorenii-invitatiintr-o-altfel-de-excursie-cu-trenul-pe-calea-ferataoravita-anina-una-dintre-cele-mai-frumoase-din$\underline{\text { tara/ }}$

[3]

https://istoriabanatului.wordpress.com/2011/02/16/

[4] M. Rrusnac, Calea-ferata-Oravita-Aninamonument de patrimoniu european/

[http://www.forumtrenuri.com/t114p475-925oravita-anina]

[5] Timişoara-Baziaş track through ScudierPark on August 8, 1932. Source: ArhiveleNaţionaleTimiş (Mircea Rusnac - Banatul pe marile artere feroviare europene: linia Seghedin-TimişoaraBaziaş, $\quad$ https://istoriabanatului. wordpress.com/2012/02/19/mircea-rusnac-banatulpe-marile-artere-feroviare-europene-liniaseghedin-timisoara-bazias/accessed April 2016

[6] Ş. Lacriţeanu, I. Popescu, Istoricul tracţiunii feroviare din România, vol. I, Bucureşti, 2003

[7]

https://istoriabanatului.wordpress.com/2011/09/06/ mircea-rusnac-cea-mai-veche-cale-ferata-dinromania-oravita-bazias/

[8] http://www.banaterra.eu/romana/popoviciugheorghe-cateva-date-mai-putin-cunoscute-legatede-constructia-si-circulatia-trenurilor-pe http://drumliber.ro/10-motive-ca-sa-mergi-pecalea-ferata-oravita-anina/

[9] http://www.banaterra.eu/romana/popoviciugheorghe-cateva-date-mai-putin-cunoscute-legatede-constructia-si-circulatia-trenurilor-pe

[10] http://www.banatuldemunte.ro/2009/06/cutrenu-oravita-anina-33km-in-2h/

http://www.welcometoromania.ro/Oravita/Oravita Oravita Anina r.htm

[11]

http://www.intercultural.ro/turismintercultural/Cale a-Ferata-Anina-Oravita.html

[12] Banatul în relaţiile internaţionale, Evenimente, Istoria Aninei, Istoria Oraviţei, monumente istorice,

https://istoriabanatului.wordpress.com/2011/02/16/ mircea-rusnac-calea-ferata-oravita-anina-

monument-de-patrimoniu-european/

[13]

https://istoriabanatului.wordpress.com/2012/02/19/

Mircea-rusnac-banatul-pe-marile-artere-feroviareeuropene-linia-seghedin-timisoara-bazias/

[14]

https://istoriabanatului.wordpress.com/2010/11/17/ mircea-rusnac-pe-urmele-caii-ferate-resitalindenfeld-delinesti/Mircea Rusnac - Pe urmele căii ferate Reşiţa-Lindenfeld-Delineşti

[15] ***, ANALELE BANATULUI. Serie noua, ARHEOLOGIE-ISTORIEXVIII, 2010, EDITURA MEGA, Cluj-Napoca, 2010, Colegiul de redactie Dan Leopold CIOBOTARU, director al Muzeului Banatului si altii, http://www.muzeulbanatului.ro/publicatii/anale 10_14.pdf, accessed 17.04.2016 